\title{
Nos limites da civilização: história e historiografia da classe trabalhadora no Mato Grosso do Sul
}

\author{
In the limits of civilization: History and historiography of the \\ working class in Mato Grosso do Sul
}

\section{Vitor Wagner Neto de Oliveira*}

\begin{abstract}
Resumo: Neste artigo apresentamos levantamento da historiografia produzida nas últimas quatro décadas sobre o mundo do trabalho no Mato Grosso do Sul, destacando a diversidade de temas, sujeitos e fontes, que tem contribuído para ampliar e aprofundar a interpretação da região como constituinte do todo nacional em interfaces com a transnacionalidade, em vista de suas características fronteiriças que demarcam especificidades na formação da classe trabalhadora. Partimos de um debate sobre as noções - nem sempre explícitas e nem sempre publicamente admitidas - de centro e de periferia nas historiografias nacionais que contagiam, também, a historiografia social do trabalho. Para tanto, inicialmente, faz-se breve incursão sobre as fontes e a historiografia do movimento operário em países da Bacia Platina (Argentina, Uruguai e Paraguai), com foco na compreensão de dicotomias sintetizantes de regiões interioranas, presentes em parte do movimento operário e da historiografia desses países, tais como: ocidente/oriente, civilização/barbárie, centro/periferia, litoral/sertão.
\end{abstract}

Palavras-chave: historiografia; classe trabalhadora; Mato Grosso do Sul.

Abstract: In this article we present historiography survey, produced in the last four decades, about the world of work in Mato Grosso do Sul, highlighting the diversity of themes, subjects and sources that have contributed to amplify and deepen the interpretation of the region, understanding it as part of all national, in interface with the transnationality in view of it's frontier characteristics that demarcate specifications in the formation of the of the working class. We start from a debate about the notions - not always explicit and not always publicly

* Doutor em História Social do Trabalho pela Universidade Estadual de Campinas (Unicamp). Professor Associado da Universidade Federal de Mato Grosso do Sul (UFMS). ORCID: https://orcid.org/0000-00032008-4195. E-mail: vitor.oliveira@ufms.br. 
admitted - of downtown and periphery in the national historiographies that contaminate, also, the social historiography of work. Therefore, initialy it is made brief incursion on the sources and historiography of the labor movement in countries of the Platinum Basin (Argentina, Uruguay and Paraguay), with focus on the comprehension of synthethizing dichotomies of inland regions, partly present in the labor movement and in the historiography of these countries, such as: west/east, civilization/barbarismo, downtown/periphery, coastline/hinterland.

Keywords: historiography; working class; Mato Grosso do Sul.

\section{Introdução}

$\mathbf{N}$ A PRIMEIRA PARTE DESTE ARTIGO faz-se um debate sobre as noções de centro e de periferia nas historiografias nacionais, presentes também na historiografia social do trabalho. Os conceitos Ocidente/Oriente construídos historicamente, a partir ao menos da Idade Moderna, pelos europeus para opor o Ocidente moderno, católico e civilizado ao Oriente arcaico, exótico e incivilizado foram adotados pelo movimento operário organizado da primeira metade do século XX; e os encontramos ainda na historiografia quando esta se divide em nacional/local, centro/periferia, centro/interior, litoral/sertão, sul/norte e leste/oeste.

Os estudos recentes sobre os mundos do trabalho nos séculos $\mathrm{XIX}$ e $\mathrm{XX}$, em regiões fora do eixo Rio de Janeiro-São Paulo, ${ }^{1}$ têm demonstrado que para além das singularidades regionais, as formas de exploração da força de trabalho compulsória e ou assalariada, como também a resistência da classe trabalhadora, guardam relações de proximidade com o que se dava nessas regiões centrais, política e economicamente, mas também estabelecem distanciamentos ao desvelar outros sujeitos e outras histórias nas relações de trabalho e de resistência, de produção e reprodução da vida.

Para contribuir com este debate, na segunda parte do artigo faz-se levantamento de dissertações e teses produzidas em programas de pós-graduação em História que têm como foco o mundo do trabalho no Sul de Mato Grosso e Mato Grosso do Sul, destacando a diversidade de temas, sujeitos e fontes, que têm contribuído para a ampliação e aprofundamento da história do trabalho e dos trabalhadores no Brasil. Ainda neste segundo tópico constrói-se uma apresentação integrada entre as pesquisas, com intuito de dar uma visão geral do campo, a partir de uma breve análise dos temas tratados nos trabalhos acadêmicos e as relações com o problema inicialmente colocado, qual seja: o estudo da história do trabalho e dos trabalhadores no sertão como contribuição para a historiografia do mundo do trabalho no Brasil e na região platina.

1 Levantamento amplo da produção de pesquisas sobre a história operária fora do eixo Rio-São Paulo encontra-se em PETERSEN, Silvia Regina Ferraz. Levantamento da produção bibliográfica e de outros resultados de investigação sobre a história operária e o trabalho urbano fora do eixo Rio-São Paulo. Cadernos AEL, Campinas, v. 14, n. 26, p. 257-344, 2009. 
Finalizamos o artigo apontando possibilidades abertas pelos trabalhos analisados e as perspectivas da historiografia social do trabalho voltada para os sertões.

\section{A fronteira da civilização}

O CONCEITO HISTORICAMENTE CONSTRUíDo de "sertão" tem seu paralelo com o Oeste, o Norte e o Nordeste, o árido ou a floresta, a ausência e a abundância, o adentrar o interior enfim. ${ }^{2} \mathrm{O}$ "sertão", mais do que uma geografia da paisagem, trata de uma geografia humana, em que pese o tom centrado na paisagem que aparece nas descrições desses espaços feitas pelos viajantes e cientistas naturais ou da saúde da passagem do XIX para o XX.

O que de certa forma sintetiza o conceito de "sertão" em diversas narrativas é a "ideia de distância em relação ao poder público e a projetos modernizadores", denotando a necessidade de "civilização" versus a "barbárie", como demonstrado por Nísia Lima: "para os intelectuaiscientistas do primeiro período republicano, sertão integra o mesmo campo semântico de incorporação, progresso, civilização e conquista". ${ }^{3}$

Nessa perspectiva, "sertão": "é concebido como um dos polos do dualismo que contrapõe o atraso ao moderno, e é analisado, com frequência, como o espaço dominado pela natureza e pela barbárie. No outro polo, litoral não significa simplesmente a faixa de terra junto ao mar, mas principalmente o espaço da civilização". ${ }^{4}$

O "sertão" começa em uma linha imaginária que divide o Ocidente do Oriente. Para a Europa, a América Latina era, ou continua sendo, o Oriente incivilizado. Em terras brasileiras essa linha recua em direção ao oeste e norte e, compreendeu, até o início do século XX, parte expressiva de São Paulo, Minas Gerais e Paraná, e os estados de Goiás, Mato Grosso, seguindo em direção à Amazônia e ao semiárido. Para além da fronteira nacional, o conceito de "sertão" pode incorporar, também, os países vizinhos como Bolívia e Paraguai.

Essas definições modernas que estiveram presentes nas teorias e obras dos positivistas, por exemplo, da passagem do século XIX para o XX, em diversas nações, também permearam a compreensão do movimento organizado dos trabalhadores, sejam os socialistas ou mesmo os libertários anarquistas.

Uma classe operária industrial dotada de consciência política foi uma imagem ocidental construída por grande parte das organizações dos trabalhadores no século XX. Os trabalhadores e ou movimentos que não se enquadravam à imagem preconcebida de organização combativa, não eram merecedores de maior atenção por parte dos militantes.

2 Sobre o "sertão" na história do Brasil ver: AMADO, Janaina. Região, sertão, nação. Estudos históricos, Rio de Janeiro, v. 18, n. 15, p. 145-151, 1995. Sobre a construção da imagem de Mato Grosso do sertão, da fronteira e não civilizado, ver: GALETTI, Lilya da Silva Guedes. Nos confins da civilização: sertão, fronteira e identidade nas representações sobre Mato Grosso. 2000. Tese (Doutorado em História) - Faculdade de Filosofia, Letras e Ciências Humanas, Universidade de São Paulo, 2000.

3 LIMA, Nísia Trindade. Missões civilizatórias da República e interpretação do Brasil. História, ciências, saúdeManguinhos, Rio de Janeiro, v. 5, suplemento, p. 163-193, julho de 1998.

4 Ibidem. 
Para muitos militantes europeus que circulavam pela América do Sul, os trabalhadores e organizações operárias do novo mundo estavam atrasados, se comparados ao movimento europeu. Da mesma forma, parte dos militantes que atuavam na região da Bacia do Prata também tinha essa visão de lugares fora das cidades-polos, para países como o Brasil e o Paraguai.

Aos militantes dos centros urbanos fervilhantes do início do século $X X$, como Buenos Aires, o movimento operário ali organizado era o espelho do movimento europeu e exemplo a ser seguido. A fronteira limitadora do movimento ocidental civilizado se deslocava para o norte argentino e o Paraguai. Mesmo o Brasil, por vezes, era visto como um país que carregava ainda em suas relações de trabalho o peso do escravismo, portanto atrasado. No Brasil, a fronteira da civilidade operária se estabelecia a oeste e norte.

Se a revolução socialista seria fruto da ação operária, esta viria da cidade moderna, e não do "deserto humano". Da mesma forma, para a conquista de um mundo sem senhores, sem governo, haveria de ter este poder para ser derrubado. No lugar da barbárie natural, em que o homem é subjugado pela natureza, não haveria espaço para a luta de classes.

A luta libertária do final do XIX e início do XX tinha o seu limite nas fronteiras impostas pela modernidade capitalista. $O$ trabalhador rural, o peão, os milhares de trabalhadores dos "sertões" não eram merecedores da liberdade, pois esta deveria ser conquistada e, para tanto, a "consciência de classe" é que determinaria a vitória. O "sertão", nesse entendimento, é ausente de consciência de classe.

Se no Brasil a divisão se dava entre o litoral e o interior (civilização e sertão), na Argentina a dicotomia era talvez mais simples em vista da espécie de monopólio cultural e econômico exercido por Buenos Aires, hegemonia conquistada no processo de configuração da república em que se enfrentaram forças políticas e econômicas divididas em vista da localização provincial (norte, litoral fluvial e porto de Buenos Aires). Para além da província bonaerense, a imagem que se tinha - se nos guiarmos pelos relatos dos viajantes ${ }^{5}$ e também de alguns militantes do movimento operário - era de um continente mestiço em que a natureza dominava o homem.

A contradição dos militantes operários não era apenas aparente. Ao mesmo tempo em que a poderosa Federación Obrera Maritima da Argentina se gabava de seu cosmopolitismo nas primeiras décadas do século $X X$, da influência exercida em diversos portos do Cone Sul americano, internamente se reproduzia o preconceito que circulava nas ruas da capital argentina em que se dava a diferenciação entre o trabalhador imigrante europeu e os nacionais ou criollos. ${ }^{6}$ Esses últimos eram tratados com desprezo e a eles era imputada a pecha de fura-

5 Para a discussão da "transposição" da dicotomia "centro" versus "periferia" da relação Europa versus América, para a relação Buenos Aires versus norte argentino, especialmente Misiones, ver: ARANHA, Bruno Pereira de Lima. De Buenos Aires a Misiones: civilização e barbárie nos relatos de viagens realizadas à terra do mate (1882-1898). 2014. Dissertação (Mestrado em Integração da América Latina) - Programa de Pós-Graduação em Integração da América Latina, Universidade de São Paulo, 2014.

6 Sobre a relação FOM e movimento operário no norte argentino e Paraguai, ver: OLIVEIRA, Vitor Wagner Neto 
-greves. A contradição maior é que grande parte dos trabalhadores marítimos filiados à FOM era composta de nacionais, denominados genericamente de criollos, e que poderia ser tanto o argentino do interior quanto o uruguaio de fora de Montevidéu ou o paraguaio. ${ }^{7}$

Sobre o preconceito dos imigrantes em relação aos nacionais argentinos, Andreas Doeswijk comenta em nota que:

[...] a parte de algumas veias racistas, presentes ainda entre os redentores internacionalistas da humanidade - poderiam ter certos fundamentos históricos. A polícia era composta majoritariamente por criollos, os trabalhadores do interior e os peões das estâncias agrícolas pareciam imunes à sindicalização e com certa frequência se traziam do interior turmas de fura-greves para fazer fracassar a luta sindical. [...] Para os empresários e os operários em greve eram crumiros; para eles mesmos estavam lutando pela sobrevivência e afincados em seu lugar de trabalho poderiam mudar de atitude e demonstrar sua tomada de consciência [...] (1998, p. 166). ${ }^{8}$

Este comentário do autor nos coloca outro problema de continuidade: a visão do trabalhador nacional do interior - o criollo na Argentina ou o caipira e caboclo no Brasil - como atrasado se perpetuou na historiografia operária e se reproduz ainda hoje. Sabemos que a historiografia do trabalho ou sobre os mundos do trabalho no Brasil, na Argentina e no Uruguai teve a sua origem nos escritos dos militantes operários do início do século $X X$, por sua vez esses militantes não estavam isentos dos preconceitos, inclusive os formulados pelas teorias do darwinismo social do final do século XIX, como a eugenia. O problema é a permanência dessa visão no decorrer do século XX chegando ao presente, seja ela explícita ou implícita. Mesmo admitindo-se que os trabalhadores rurais ou do interior são fazedores de história de resistência - como faz Doeswijk ${ }^{9}$ ao referenciar as lutas dos trabalhadores do tanino no Chaco argentino, nos engenhos de Tucumán, nas adegas de Mendoza, nas montanhas da Patagônia -, esses a fazem por influência dos citadinos, uma consciência de fora para dentro.

Outros autores argentinos chamaram atenção para essa dicotomia cidade versus interior na historiografia operária. Mirta Lobato e Juan Suriano salientam que

Os acontecimentos da Patagônia que significaram a mobilização dos peões rurais contra as condições de trabalho subumanas nas instâncias ficaram imortalizados na solitária obra de Bayer (1973). Por outro lado, o campo argentino com seu potencial conflituoso foi geralmente marginalizado da historiografia cujo centro social e político, assim como sua força revolucionária, só podia ser encarnada pelos trabalhadores industriais urbanos. ${ }^{10}$

de. Movimiento obrero transnacional en el Cono Sur Americano a principios del siglo XX: los marítimos de los ríos Paraná y Paraguay. Revista de estúdios marítimos y sociales, año 12, n. 14, p. 196-226, enero de 2019.

7 DOESWIJK, Andréas. Entre camaleones y cristalizados: los anarco-bolcheviques rioplatenses, 1917-1930. 1998. Tese (Doutorado em História) - Faculdade de Filosofia e Ciências Humanas, Universidade Estadual de Campinas, Campinas, 1998. p. 166.

8 Ibidem. As citações de fontes castelhanas foram traduzidas livremente para facilitar a leitura e o entendimento.

9 Ibidem, p.179.

10 LOBATO, Mirta Zaida; SURIANO, Juan. Acerca de la historia de los trabajadores. In: LOBATO, Mirta (dir.). La historia de los trabajadores argentinos (guía bibliográfica). Buenos Aires: Grupo de Trabajo Movimiento Obrero y Sectores Populares/Universidad de Buenos Aires/Universidad Nacional de Cordoba/Universidad Nacional de Rosario, 2000 (CD). s/p. 
Influenciar trabalhadores é algo muito próximo do que se denomina de conscientizar. Os dois termos são bastante problemáticos, mas foram, e permanecem sendo, objetivos dos militantes operários, especialmente dos libertários que tinham na palavra e na educação meios privilegiados para a ação.

O periódico anarquista La Batalla, publicado em Montevidéu a partir de 1915, expressava bem esta vontade. O editorial da primeira quinzena de maio de 1915 salienta a necessidade de propagar os ideais libertários para os demais países da América Latina, para tirar do atraso o proletariado desses países. O editorial destaca o esforço dos argentinos neste intuito, a partir do jornal La Protesta e sentencia: "Se no Brasil, Peru e Chile, por exemplo, consideramos que o desenvolvimento da teoria anarquista e da ação emancipadora são inferiores intelectualmente à Argentina ou ao Uruguai, com melhor razão devemos nos dirigir a esses lugares nossa propaganda solidária, para que os resultados sejam, além de práticos, uniformes e frutíferos".11

Para os anarquistas de La Batalla, fora do eixo Buenos Aires-Montevidéu parecia não haver vida inteligente ao sul do Equador. Em artigo assinado por Alejandro Aera, dois meses depois do editorial citado, a imagem da América Latina, especialmente do Brasil, como um "sertão" de ideias surge com mais ênfase. Vale a citação longa, pois expressa de forma exemplar o que vimos afirmando:

A América é terra virgem em matéria de ideias. Qualquer um que teve oportunidade de viajar pelos países deste continente, exceção feita à Argentina e ao Uruguai, constatará o que tenho dito.

Em relação ao Brasil, há muitos companheiros que alimentam concepções errôneas referentes ao seu movimento anarquista. Eu, que o conheço, por estar ali por duas vezes, posso afirmar que ali não há um sério movimento que mereça ser classificado de anarquista. Os escassos companheiros do país vizinho são absorvidos totalmente pelo grosso da população. [...]

Bastante esforço tem feito os companheiros de Buenos Aires para estreitar relações com os do Rio de Janeiro, e todos os esforços foram em vão pela falta nesta última cidade do elemento que tornam recíprocas as relações.

No pretendido congresso anarquista realizado na capital carioca, e que como todos sabem, estiveram presentes delegados de Buenos Aires, se acordou constituir um comitê de relações internacionais, composto por três indivíduos. Finalizado o congresso formou-se o comitê e até o último dia de minha partida do Rio [...] nenhum de seus membros me procurou. E em verdade, para que havia de reunir-se o comitê? Que movimento há no Rio para que os obrigue a reunir-se a fim de trocar experiências com os companheiros da Argentina e do Uruguai?

A FORA desejando manter relações com o proletariado brasileiro, me designou delegado junto à Confederação Operária Brasileira. Minha missão teve que finalizar antes de começar, pois da COB só existia um selo e um par de indivíduos encarregados de sua custódia.

Apesar de tudo, os companheiros de Buenos Aires ainda continuam correspondendo-se com os do Rio. A respeito disso, posso dizer que a correspondência é recebida por um companheiro, que uma vez lida se limita

11 SOBRE una iniciativa (cuestiones internacionales). La Batalla: Periodico de ideas y crítica, año I, n. 19, $1^{\text {a }}$ quincena, mayo de 1915, p. 1 (Biblioteca Nacional del Uruguay). O editorial é finalizado no número seguinte. 
a guardá-la no bolso, sendo o alcance de tal correspondência completamente nulo. Não pode, tão pouco, ser de outra maneira, pois ainda que o companheiro aludido se propusesse a praticar as iniciativas que a correspondência sugere, se encontraria com a falta de homens capazes para levá-las ao terreno dos feitos.

O que se passa no Rio é corrente em São Paulo, e de Santos posso dizer, porque assim me autoriza a carta que um companheiro desta localidade acaba de enviar, que não há propaganda anarquista de nenhum gênero. Nem sequer conta com o movimento sindicalista que outrora a destacava da apatia geral do país, e que o valia a classificação de 'Barcelona Brasileira'.

E falando de anarquismo e de anarquistas, não se pode pensar no resto desse imenso país onde só se exerce a mais implacável exploração [...] e que o faz parecer como uma prolongação da África Central.

Se os anarquistas do Brasil, ainda sendo poucos, exercessem alguma influência sobre seu povo, as relações com eles teriam razão de ser [...] porém, ao carecer desta influência, o objetivo das relações fica descartado [...].

O que disse referente ao Brasil pode ser estendido ao Chile, Paraguai e Peru, onde a propaganda anarquista é incipiente, e por essa razão os povos desses países não se encontram a altura necessária e que é indispensável para manter-se uma inteligência internacional cujos resultados sejam de positivo valor para a difusão das ideias e das lutas que estas provocam com os poderes constituídos. ${ }^{12}$

O "pretendido congresso anarquista" do Rio de Janeiro, a que o militante faz referência, pode ser o congresso anarquista sul-americano convocado pela Confederação Operária Brasileira (COB), que seria realizado em 1915. No contexto da Primeira Grande Guerra, a COB havia convocado um Congresso Internacional da Paz para o Rio de Janeiro, em vista do cancelamento de um encontro similar na Espanha. Nesse congresso de outubro de 1915 no Brasil teriam participado dois militantes libertários argentinos, um provavelmente o autor do artigo acima citado, além de representantes de Portugal e da Espanha. Na sequência do Congresso da Paz, a COB convocou o congresso anarquista sul-americano. Todavia, em vista da presença limitada de representantes da América do Sul - apenas os dois militantes argentinos -, o encontro transformou-se em Congresso Anarquista Nacional do Rio de Janeiro que, entre outras deliberações, salientou a necessidade de reforçar a imprensa anarquista, uma vez que não tinha um periódico dedicado exclusivamente ao anarquismo. ${ }^{13}$

A COB - central sindical libertária criada no I Congresso Operário de 1906, que passou a funcionar efetivamente no Rio de Janeiro em 1908 - referida pelo militante argentino atuou até o início de 1915, com interrupção de 1909 a 1913. A COB é considerada pelos historiadores brasileiros como uma experiência importante pela sua atuação em um período de agitação

12 RELACIONES internacionales. La Batalla: Periodico de ideas y crítica, año I, 1 jul. de 1915, p. 1 (Biblioteca Nacional del Uruguay).

13 DULLES, John W. F. Anarquistas e comunistas no Brasil (1900-1935). Rio de Janeiro: Nova Fronteira, 1977. p. 37-8; HARDMAN, Francisco Foot; LEONARDI, Victor. História da indústria e do trabalho no Brasil: das origens aos anos vinte. São Paulo: Global, 1982. p. 334-346; OLIVEIRA, Vitor Wagner Neto de. Nas águas do Prata: os trabalhadores da rota fluvial entre Buenos Aires e Corumbá (1910-1930). Campinas: Ed. Unicamp, 2009. p. 228. 
política dos trabalhadores. O II Congresso Operário, convocado pela comissão reorganizadora da COB, aconteceu no Rio de Janeiro em 1913 e retomava os princípios da ação direta do anarcossindicalismo aprovados no congresso de 1906.

Os relatórios apresentados no II Congresso Operário Brasileiro por diversas organizações, que relataram a existência de movimento organizado em vários pontos do país, diziam também das atividades internacionalistas, como a da Federação Operária do Rio de Janeiro que manteve relação com a Federación Obrera Argentina. Conforme a leitura dos relatórios feita por Hardman e Leonardi, acima citados, desde 1907 a Federação do Rio de Janeiro mantinha contato com a da Argentina na tentativa de realizar um congresso operário sul-americano.

No mais, na década de 1920, e mesmo antes, os contatos entre militantes e organizações operárias do Cone Sul americano continuariam ocorrendo em bases socialistas e comunistas. A Primera Conferencia Socialista y Obrera Panamericana convocada pelo Partido Socialista Argentino reuniu diversos delegados de partidos e associações operárias do continente, entre os dias 26 e 30 de abril de $1919 .{ }^{14}$ A Conferencia Sindical Sudamericana contra la Guerra (do Chaco), em 1929, na capital uruguaia, se tornou um espaço de debate das ideias internacionalistas trazidas pelos delegados dos diversos países participantes, dentre os quais os representantes das nações diretamente envolvidas no conflito, o Paraguai e a Bolívia, além do Brasil, da Argentina, do Uruguai e do Peru. ${ }^{15}$

O autor do artigo aqui relacionado, portanto, poderia até estar certo da avaliação que fez do movimento anarquista no Brasil, da fragilidade e da pouca importância dessa ideologia entre os operários do Rio de Janeiro, de São Paulo e de Santos. A questão que se coloca é a de que da inexistência do movimento anarquista se entende a inexistência de movimento operário e de resistência dos trabalhadores. Como admitir a resistência ao patronato onde não há consciência de classe? Aí, só há espaço para a "exploração implacável".

A comparação do Brasil com a África Central parece não ser apenas uma retórica do discurso, mas tenta se afirmar nas evidências. Em diversos espaços argentinos já se fez essa relação em vista da presença da população negra no Brasil e a herança da escravidão. Nesse sentido, o Brasil - como também os demais países citados no artigo - está a oeste de Buenos Aires e de Montevidéu.

Especialmente o Paraguai surge em alguns relatos de militantes, nas páginas dos periódicos, como que uma extensão do norte argentino no que se refere à ausência ou fragilidade

14 Estavam representadas organizações do Peru, da Bolívia, do Chile, do Uruguai, do Paraguai e do Equador, sendo que os delegados do Brasil e dos Estados Unidos da América do Norte "anunciaram que se fariam presentes na Conferência”. GAONA, Francisco. Introducción a la historia gremial y social del Paraguay. (Tomo II). Asunción: Litocolor, 1987. p. 143.

15 OLIVEIRA, op. cit., 2009, p. 224. Estavam presentes delegados das seguintes organizações: Comitê Pró-Confederação Sindical Latino-Americana, patrocinadora da Conferência, a Confederação Nacional do Trabalho da Bolívia; a União Operária do Paraguai; o Centro Operário Regional do Paraguai; a Federação Operária de Lima, Peru; o "Comitê Central Geral do Trabalho" e a Federação Sindical Regional do Rio de Janeiro, Brasil; a União Sindical Argentina, e o Bloco de Unidade do Uruguai. GAONA, op. cit., p. 150. 
do movimento operário. Quando se admite a existência do movimento, quase sempre é como uma prolongação do argentino, em vista da influência exercida pelos trabalhadores marítimos.

O militante e escritor paraguaio da primeira metade do século XX Francisco Gaona, ao discorrer sobre o embate de duas tendências sindicais no Paraguai - a anarcossindicalista da Federación Obrera Regional del Paraguay - FORP e a "reformista" do Centro General de Obreros, organização criada em 1907 para se contrapor à FORP -, ressalta que o Paraguai "era uma caixa de ressonância do que ocorria na Argentina", reproduzindo-se em Assunção os debates ideológicos que aconteciam em Buenos Aires, entre a Federación Obrera Regional Argentina - FORA e os socialistas. ${ }^{16}$

Os ideais propagandeados pelos militantes uruguaios e, especialmente, argentinos pareciam consolar os militantes paraguaios que lutavam contra o que eles consideravam apatia e falta de consciência dos trabalhadores. Em artigo publicado no periódico uruguaio $\mathrm{La}$ Batalla, o paraguaio Leopoldo Giménez faz referência ao internacionalismo dos anarquistas argentinos e uruguaios e comenta o trabalho nos ervais e matas paraguaias, apontando para a possibilidade de levantes, uma vez que o proletariado paraguaio podia contar com um instrumento de conscientização há oito meses, que era o periódico Promoteo: "Oito meses de combate contínuo que hoje levantou a consciência do povo". ${ }^{17}$

A historiografia reproduz como verdade, mais uma vez, no caso paraguaio, o que se deu em outros lugares: não houve movimento operário no Paraguai, logo não tem história a ser contada. Essa historiografia, todavia, reproduz o discurso de parte dos militantes paraguaios que não enxergava movimento organizado no Paraguai, porque o olhar procurava a versão europeia por aproximação via Rio da Prata.

Nesse sentido, François Chartrain ${ }^{18}$ salienta que há abundância de trabalhos sobre as disputas entre os grupos dominantes no Paraguai, colorados e liberais, enquanto o estudo "de grupos sociais majoritários tem sido ignorado", com exceção do militante e escritor da primeira metade do século XX no Paraguai Francisco Gaona, em sua obra "Introducción a la historia gremial y social del Paraguay" (escrita na década de 1950, constitui-se em coletânea de documentos sobre o movimento operário da primeira metade do século XX no Paraguai).

O exame do período de 1870 a 1936 é rechaçado por muitos paraguaios, em vista de ser identificado como "de la 'politiquería', de la 'baja mentalidad política'”. Remetem-se mais ao tempo anterior à guerra da Tríplice Aliança a fim de buscar ali a origem dos modelos de desenvolvimento autônomo do Paraguai. Para Chartrain, a reabilitação histórica do período

16 Ibidem, p. 57.

17 GIMÉZEZ, Leopoldo Ramos. Del Paraguay: los esclavos de los yerbales y obrajes. La rebelión inevitable. La Batalla: Periodico de ideas y crítica, año 2, n. 22, primera quincena de jul. de 1916, p. 4 (Biblioteca Nacional del Uruguay).

18 CHARTRAIN, François. El mundo del trabajo em Paraguay entre 1870 y 1936: reflexiones sobre El estúdio histórico. Traducción de Rubén Bareiro Saguier (p.289-296). In: CENTRO PARAGUAYO DE ESTUDIOS SOCIOLOGICOS. Pasado y presente de la realidad social paraguaya. Asunción: Volume I, 1995. p. 289. 
1870 a 1936, por outro lado, só é possível mediante a mudança de foco de análise: do centro do poder político e econômico para "referir-se à atitude dos grupos sociais governados". ${ }^{19}$

Para alguns militantes, Assunção era a última fronteira da civilização. Dali rio acima o homem era uma insignificância diante do Chaco, ou mesmo se confundia com a natureza. Em 1908, Rafael Barret, um conhecido militante e intelectual libertário espanhol que atuou no Paraguai e na Argentina, ao passar por terras mato-grossenses fugindo de perseguições em Assunção, descreveu a percepção do lugar. Na primeira cidade em território brasileiro, Porto Murtinho no Mato Grosso, o viajante foi obrigado a pernoitar e arranjou hospedagem nas oficinas da Cia. Matte Larangeira, empresa conhecida na imprensa operária argentina e paraguaia da época como ambiente de exploração da força de trabalho indígena e paraguaia, uma espécie de enclave industrial. A confissão de que "Ihe repugnara encostar-se na cama dos negros" 20 é reveladora dos limites e contradições da ideologia libertária que ele divulgava nas páginas dos jornais assuncenhos e do Prata. De certa forma, toda cama no Brasil, para esse militante intelectual, era cama dos negros.

Ao propor narrar a história dos trabalhadores do sertão ou no sertão, deve-se estar atento a essas nuances da história (nas fontes) e da historiografia. Desde ao menos a década de 1980, e com mais constância a partir da segunda metade da década de 1990, estudiosos têm se voltado para essas outras histórias. O desafio colocado é o seguinte: como deixar de reproduzir as leituras reducionistas que não enxergavam classe trabalhadora para além da fronteira citadina, para além do horizonte ocidental? Esse é um problema que não tem solução fácil, uma vez que somos criação e criadores da imagem do ocidente. Falamos a partir dele, porque formados nessa tradição. O esforço por construir leituras Sul-Sul, ou "originais" algo como "decolonial", por si só, não rompe com a tradição teórico-filosófica da qual somos produtores e reprodutores. O desafio é, mais uma vez, não se cegar para o caleidoscópio de outras histórias, outros sujeitos e outras experiências.

Partindo das mesmas matrizes ideológicas urbano-centristas que embasaram os militantes e os pesquisadores nos séculos $\mathrm{XIX}$ e $\mathrm{XX}$, e reformulando/construindo novos conceitos, novas metodologias e recorrendo a novas fontes, os estudiosos que se dedicam à história do trabalho e dos trabalhadores nos sertões têm contribuído para tornar essas histórias conhecidas como parte e à parte do todo nacional.

\section{Outras histórias na historiografia}

OUTRA HISTÓRIA é possível ser vislumbrada. Essa história tem sido contada já faz algum tempo pela historiografia sul-mato-grossense que se dedica ao estudo das pessoas comuns, dos trabalhadores, na região. Por vezes, o tema aparece em trabalhos que têm como foco a

19 Ibidem, p.189-290.

20 BARRETT, Rafael. Cartas intimas. Com notas de su viuda, Francisca Lopez Maiz de Barrett. Montevideo: Biblioteca Artigas, 1967. p. 37. 
política formal e a economia, mas que não se fecham para outros sujeitos. Narrativas que demonstram haver história humana, história de trabalhadores no oeste, histórias de resistência e de contradição, as quais precisam ser desnudadas para que o debate sobre a historiografia do trabalho não reproduza o discurso do centro-periferia.

Em busca de uma sistematização da historiografia acerca do mundo do trabalho em Mato Grosso do Sul, apresentaremos neste tópico a compilação da produção de pesquisas nesta área. Para este fim fizemos algumas opções: a) buscamos dissertações de mestrado e teses de doutorado que abordam com alguma centralidade os temas "trabalho", "trabalhadores(as)" e "operários(as)", deixando de fora aquelas pesquisas que têm esses temas como secundários (com isso, muita coisa ficou de fora); b) o foco recai sobre os trabalhos produzidos na academia, por entender que é a partir da criação dos cursos universitários de História que se forma uma tradição ou cultura historiográfica local, se assim podemos dizer; c) a busca se restringiu ao universo dos cursos de pós-graduação strictu sensu (mestrado e doutorado acadêmico) ${ }^{21}$ de História, o que exclui do levantamento muitas pesquisas em áreas como Educação, Geografia, Sociologia e Ciências Sociais que muito têm contribuído nos estudos da classe trabalhadora no Sul de Mato Grosso e Mato Grosso do Sul.

Não é objeto, portanto, a escrita não acadêmica dos memorialistas, por exemplo, mesmo reconhecendo que este âmbito da produção da História perpassa a universidade. Ao delimitar a abrangência territorial da história do trabalho e dos trabalhadores "no" Mato Grosso do Sul, nos referimos ao território que veio a ser, em 1979, essa unidade da federação e que até então era parte de Mato Grosso uno. Por isso, para o período anterior a 1979, utilizamos uma denominação que se tornou consensual na historiografia regional, qual seja: "Sul de Mato Grosso".

A criação dos primeiros cursos de graduação em História no estado acontece em 1970, em três unidades da Universidade do Estado do Mato Grosso (UEMT), no sul do estado, e em 1971, na Faculdade Dom Aquino (atual Universidade Católica Dom Bosco), em Campo Grande, concomitante ao início da edificação dos primeiros cursos de pós-graduação strictu sensu nos principais centros urbanos do país. Do estado de São Paulo, sobretudo, foram oriundos os primeiros historiadores profissionais para compor o corpo docente dos cursos de História da Universidade Federal de Mato Grosso do Sul (UFMS), especialmente a partir da década de 1980. ${ }^{22}$

A chegada desses jovens professores dinamizou a vida acadêmica e a profissionalização da História acadêmica possibilitada pela contratação de professores por concurso público,

21 Algumas teses e dissertações arroladas foram publicadas em forma de livros, mas optamos em fazer a referência ao texto originalmente defendido na pós-graduação porque esse é o foco. Reconhecemos, contudo, que a publicação de livros e a disseminação de revistas científicas especializadas impactam na produção científica em vista da publicização do tema. Da mesma forma, contribuem os livros que não resultam de teses ou dissertações, por vezes nem de pesquisas acadêmicas.

22 OLIVEIRA, Vitor Wagner Neto de. Mato Grosso do Sul: apontamentos da história da historiografia. In: X ENCONTRO DE HISTÓRIA DE MATO GROSSO DO SUL, Simpósio Internacional de História e XIII Semana de História da UFMS/CPTL - As muitas (in)dependências das Américas: dois séculos de história, 2010, Três Lagoas-MS. Anais [...]. Três Lagoas: UFMS, p. 2061-2074. Disponível em: http://www.ndh.ufms.br/wp-anais/ Anais2010/trabalhos.html. 
em detrimento da forma anterior, quando da antiga Universidade do Estado de Mato Grosso (UEMT), em que o ingresso de professores se dava sem a necessidade de concursos.

Os professores que ingressaram na década de 1980 (já na UFMS, criada em 1980 pela federalização da UEMT), advindos, especialmente, das universidades paulistas, seriam os primeiros a cursarem a pós-graduação, nível de mestrado em História, com temas relacionados a Mato Grosso do Sul, ou Sul de Mato Grosso, ou mesmo Mato Grosso como um todo, pois a divisão oficial do território não impôs, de imediato, a divisão da historiografia.

No final da década de 1980 e no decorrer da de 1990 dois fatores oportunizaram mais acadêmicos formados em Mato Grosso do Sul alcançarem a pós-graduação: a expansão dos cursos de pós-graduação no país e uma sensível melhora acadêmica nos cursos de graduação em História no estado, com a intensificação da relação entre ensino e pesquisa.

Os acadêmicos formados no estado passaram a procurar a qualificação profissional da pós-graduação, sobretudo no estado de São Paulo, com temas sobre o Sul de Mato Grosso. Continuou, também, a migração de historiadores de São Paulo para a UFMS. Da segunda metade da década de 1990 em diante a historiografia produzida no e sobre o Mato Grosso do Sul foi bastante dinâmica. ${ }^{23}$ As pesquisas, contudo, só muito raramente se voltavam prioritariamente para o mundo do trabalho, ao passo que nas décadas de 1980 e 1990 temos apenas quatro pesquisas que abordaram as relações de trabalho na região sul de Mato Grosso, como descrito na tabela a seguir.

Tabela 1 - Compilação de dissertações e teses (décadas de 1980 e 1990) (cont.)

\begin{tabular}{|c|c|c|}
\hline \multicolumn{3}{|l|}{ Gilmar Arruda } \\
\hline \multicolumn{3}{|c|}{ Frutos da terra: os trabalhadores da Matte Laranjeira } \\
\hline Dissertação de mestrado & UNESP-Assis & 1989 \\
\hline \multicolumn{3}{|c|}{$\begin{array}{l}\text { Abordagem: estuda as relações de trabalho nos domínios da empresa ervateira Matte Larangeira, } \\
\text { do final do século XIX e primeira metade do XX, com atenção à utilização da força de trabalho de } \\
\text { paraguaios, descrevendo com detalhes as etapas de elaboração da erva. }\end{array}$} \\
\hline \multicolumn{3}{|c|}{ Isabel Cristina Martins Guillen } \\
\hline \multicolumn{3}{|c|}{$\begin{array}{l}\text { O imaginário do sertão: lutas e resistências ao domínio da Companhia Matte Larangeira (Mato } \\
\text { Grosso: 1890) }\end{array}$} \\
\hline Dissertação de mestrado & UNICAMP & Ano de defesa: 1991 \\
\hline \multicolumn{3}{|c|}{$\begin{array}{l}\text { Abordagem: analisa as relações de trabalho na Matte Larangeira com foco privilegiado nas resistências } \\
\text { ao poder da companhia estudando o mundo do erval e as formas de recrutamento de força de trabalho. }\end{array}$} \\
\hline \multicolumn{3}{|c|}{ Lúcia Helena Aleixo } \\
\hline \multicolumn{3}{|c|}{ Vozes no silêncio: subordinação e trabalho em Mato Grosso. 1888-1930 } \\
\hline Tese de doutorado & USP & Ano de defesa: 1991 \\
\hline \multicolumn{3}{|c|}{$\begin{array}{l}\text { Abordagem: pesquisa a resistência e a subordinação dos trabalhadores de norte a sul de Mato } \\
\text { Grosso, com olhar sobre a legislação estadual que forçou a proletarização da força de trabalho, via } \\
\text { expropriação do homem pobre. }\end{array}$} \\
\hline
\end{tabular}

23 Balanço amplo da historiografia sul-mato-grossense, até o ano de 2010, está em: QUEIROZ, Paulo Roberto Cimó. A historiografia sul-mato-grossense, 1968-2010: notas para um balanço. In: GLEZER, Raquel (org.). Do passado para o futuro: edição comemorativa aos 50 anos da ANPUH. São Paulo: Contexto, 2011. p. 167-185. 
Tabela 1 - Compilação de dissertações e teses (décadas de 1980 e 1990) (fim)

\begin{tabular}{|l|l|}
\hline Maria Inês Malta Castro \\
\hline O preço do progresso. A construção da Estrada de Ferro Noroeste do Brasil (1905-1914) \\
\hline Dissertação de mestrado $\quad$ UNICAMP & Ano de defesa: 1993 \\
\hline $\begin{array}{l}\text { Abordagem: trata das condições de trabalho na construção da estrada de ferro de Bauru (SP) a } \\
\text { Porto Esperança (MT), obra que trazia em seu bojo os auspícios do progresso e da modernidade, na } \\
\text { concepção de seus idealizadores. }\end{array}$ \\
\hline
\end{tabular}

Entramos no século XXI com uma produção historiográfica sobre o Sul de Mato Grosso e Mato Grosso do Sul dinâmica e consistente. Fortalecimento que se reflete na criação, em 1999, do primeiro, e ainda único, curso de pós-graduação strictu sensu acadêmico em História do estado, na UFMS, Campus de Dourados (a partir de 2005 Universidade Federal da Grande Dourados - UFGD). O mestrado, e depois doutorado, em História ampliou ainda mais as possibilidades dos estudantes graduados no estado de continuarem os estudos, e demonstra a importância da interiorização da pós-graduação no país.

Tabela 2 - Compilação de dissertações e teses (pós-2000) (cont.)

\begin{tabular}{|c|c|c|}
\hline \multicolumn{3}{|l|}{ Eudes Fernando Leite } \\
\hline \multicolumn{3}{|c|}{ Marchas na história: comitivas, condutores e peões-boiadeiros nas águas de Xarayes } \\
\hline Tese de doutorado & UNESP-Assis & Ano de defesa: 2000 \\
\hline \multicolumn{3}{|c|}{$\begin{array}{l}\text { Abordagem: estuda os trabalhadores boiadeiros em comitivas, as raízes históricas e tradições culturais } \\
\text { desses sujeitos que percorrem longas jornadas com boiadas no Pantanal sul-mato-grossense, em um } \\
\text { mundo em transformação. }\end{array}$} \\
\hline \multicolumn{3}{|c|}{ Vitor Wagner Neto de Oliveira } \\
\hline \multicolumn{3}{|c|}{$\begin{array}{l}\text { Movimento operário no Sul de Mato Grosso: avanços e recuos dos trabalhadores no Rio Paraguai } \\
(1917-1926)\end{array}$} \\
\hline Dissertação de mestrado & PUC-RS & Ano de defesa: 2000 \\
\hline \multicolumn{3}{|c|}{$\begin{array}{l}\text { Abordagem: analisa o mundo do trabalho no Sul de Mato Grosso no início do século XX, especialmente } \\
\text { a organização sindical dos trabalhadores marítimos em Corumbá. }\end{array}$} \\
\hline \multicolumn{3}{|c|}{ Alisolete A. Santos Weingartnher } \\
\hline \multicolumn{3}{|c|}{$\begin{array}{l}\text { Operários nas indústrias da construção civil: participação e luta por direitos sociais. Uma história do } \\
\text { sindicalismo em Campo Grande-MS (1928-1979) }\end{array}$} \\
\hline Tese de doutorado & UNESP-Franca & Ano de defesa: 2001 \\
\hline \multicolumn{3}{|c|}{$\begin{array}{l}\text { Abordagem: trata das organizações sindicais dos trabalhadores da construção civil em Campo } \\
\text { Grande, anterior à divisão do estado, com foco na luta por direitos. }\end{array}$} \\
\hline \multicolumn{3}{|c|}{ João Carlos de Souza } \\
\hline \multicolumn{3}{|c|}{ Sertão cosmopolita: a modernidade de Corumbá (1872-1918) } \\
\hline Tese de doutorado & USP & Ano de defesa: 2001 \\
\hline \multicolumn{3}{|c|}{ Abordagem: pesquisa a urbanização da cidade de Corumbá e os trabalhadores formais e informais. } \\
\hline \multicolumn{3}{|c|}{ Simone Anselmo Girão } \\
\hline \multicolumn{3}{|c|}{ Do ideário desenvolvimentista ao universo social carvoeiro: 1964-1994 } \\
\hline Dissertação de mestrado & UFMS/UFGD & Ano de defesa: 2003 \\
\hline
\end{tabular}


Tabela 2 - Compilação de dissertações e teses (pós-2000) (cont.)

\begin{tabular}{|c|c|c|}
\hline \multicolumn{3}{|l|}{ Ciro José Toaldo } \\
\hline \multicolumn{3}{|c|}{$\begin{array}{l}\text { O novo sindicalismo e a mobilização dos professores da rede pública estadual sul-mato-grossense } \\
\text { avanços e rupturas (1979/1992) }\end{array}$} \\
\hline Dissertação de mestrado & UFMS/UFGD & Ano de defesa: 2003 \\
\hline \multicolumn{3}{|c|}{$\begin{array}{l}\text { Abordagem: pesquisa a história da Federação dos Trabalhadores em Educação de Mato Grosso do } \\
\text { Sul - FETEMS, sucedânea da Federação dos Professores de Mato Grosso do Sul - FEPROSUL, com } \\
\text { ênfase nos anos de } 1979 \text { a } 1992 \text {. }\end{array}$} \\
\hline \multicolumn{3}{|l|}{ Jocimar Lomba Albanez } \\
\hline \multicolumn{3}{|c|}{$\begin{array}{l}\text { Sobre o processo de ocupação e as relações de trabalho na agropecuária: o extremo sul de Matc } \\
\text { Grosso (1940-1970) }\end{array}$} \\
\hline Dissertação de mestrado & UFMS/UFGD & Ano de defesa: 2003 \\
\hline \multicolumn{3}{|c|}{$\begin{array}{l}\text { Abordagem: analisa as relações de trabalho no extremo sul de Mato Grosso, no contexto de declínic } \\
\text { da indústria ervateira, a presença da política do Estado Novo para a região e o avanço das fronteiras } \\
\text { pioneiras. }\end{array}$} \\
\hline \multicolumn{3}{|c|}{ Vitor Wagner Neto de Oliveira } \\
\hline \multicolumn{3}{|c|}{$\begin{array}{l}\text { Entre o Prata e Mato Grosso: uma viagem pelo mundo do trabalho marítimo de } 1910 \text { a } 1930 \text { (Buenos } \\
\text { Aires, Montevidéu, Assunção e Corumbá) }\end{array}$} \\
\hline Tese de doutorado & UNICAMP & Ano de defesa: 2006 \\
\hline
\end{tabular}

Abordagem: análise transnacional da história de trabalho e de resistência dos marítimos que navegavam pelos portos de Mato Grosso, Paraguai, Argentina e Uruguai nas três décadas iniciais do século XX.

Edna de Falchi

Na luta por um pedaço de chão: experiência e cotidiano nos acampamentos de sem-terra do sul de Mato Grosso do Sul

\begin{tabular}{|l|l|l}
\hline Dissertação de mestrado & UFGD & Ano de defesa: 2007
\end{tabular}

Abordagem: estuda o cotidiano de luta em assentamentos do MST, FETAGRI e CUT no sul de Mato Grosso do Sul, no tempo presente.

Eva Maria Luiz Ferreira

A participação dos índios Kaiowá e Guarani como trabalhadores nos ervais da companhia Matte Laranjeira (1902-1952)

\begin{tabular}{l|l|l}
\hline Dissertação de mestrado & UFGD & Ano de defesa: 2007
\end{tabular}

Abordagem: trata da história dos indígenas Kaiowá e Guarani como trabalhadores nos ervais da Companhia Matte Larangeira, no antigo sul de Mato Grosso.

Miriam Cristina Franco Mateu

Metamorfoses no mundo do trabalho: caso do setor bancário em Dourados (1990/2000)

\begin{tabular}{|l|l|l}
\hline Dissertação de mestrado & UFGD & Ano de defesa: 2007
\end{tabular}

Abordagem: pesquisa as mudanças ocorridas no mundo do trabalho nas últimas décadas do século XX que redimensionaram as relações entre o capital e o trabalho, no setor bancário em Dourados-MS.

Zilda Alves de Moura

Cativos nas terras dos pantanais. Escravidão e resistência no sul de Mato Grosso. Séculos XVIII e XIX

\begin{tabular}{|l|l|l|}
\hline Dissertação de Mestrado & UPF & Ano de defesa: 2008
\end{tabular}

Abordagem: trata da história dos trabalhadores negros escravizados e livres, trabalho compulsório e livre de indígenas, e trabalhadores nativos na mineração, nas fazendas e portos do sul de Mato Grosso. 
Tabela 2 - Compilação de dissertações e teses (pós-2000) (cont.)

\begin{tabular}{|c|c|c|}
\hline \multicolumn{3}{|l|}{ Jose Tiaraju Rodrigues Sch } \\
\hline \multicolumn{3}{|c|}{$\begin{array}{l}\text { Exploração e violência: um estudo sobre a formação do mercado de trabalho assalariado em Mato } \\
\text { Grosso (1870-1930) }\end{array}$} \\
\hline Dissertação de mestrado & UFMT & 2008 \\
\hline \multicolumn{3}{|c|}{$\begin{array}{l}\text { Abordagem: estuda as condições de trabalho e os trabalhadores na região, após a guerra com o } \\
\text { Paraguai e na transição para o trabalho assalariado. }\end{array}$} \\
\hline \multicolumn{3}{|l|}{ Thiago Moratelli } \\
\hline \multicolumn{3}{|c|}{$\begin{array}{l}\text { Os trabalhadores da construção da estrada de ferro Noroeste do Brasil: experiências operárias em } \\
\text { um sistema de trabalho de grande empreitada. (São Paulo e Mato Grosso, 1905-1914) }\end{array}$} \\
\hline Dissertação de mestrado & UNICAMP & Ano de defesa: 2009 \\
\hline \multicolumn{3}{|c|}{$\begin{array}{l}\text { Abordagem: pesquisa a história social dos trabalhadores da construção da ferrovia nos trechos de } \\
\text { São Paulo e sul de Mato Grosso, bem como a forma de arregimentação de trabalhadores e o sistema } \\
\text { de trabalho. }\end{array}$} \\
\hline \multicolumn{3}{|l|}{ Saulo Álvaro de Mello } \\
\hline \multicolumn{3}{|c|}{$\begin{array}{l}\text { O arsenal da Marinha em Mato Grosso projeto político de defesa nacional e de disciplinarização do } \\
\text { trabalho. Do planalto à planície pantaneira }(1719-1873)\end{array}$} \\
\hline Dissertação de mestrado & UFGD & Ano de defesa: 2009 \\
\hline \multicolumn{3}{|c|}{$\begin{array}{l}\text { Abordagem: estuda os Arsenais da Marinha como projeto político de defesa nacional e de } \\
\text { disciplinarização do trabalho. A partir desses pressupostos caracteriza o processo de organização da } \\
\text { Marinha em Mato Grosso, com ênfase nas questões sociais. }\end{array}$} \\
\hline \multicolumn{3}{|l|}{ Walter Assis Alves } \\
\hline \multicolumn{3}{|c|}{ Trabalhadores têxteis em Três Lagoas: experiências de trabalho, práticas sociais e atuações políticas } \\
\hline Dissertação de mestrado & UFU & Ano de defesa: 2009 \\
\hline \multicolumn{3}{|c|}{$\begin{array}{l}\text { Abordagem: analisa a história recente do operariado industrial no leste de Mato Grosso do Sul, } \\
\text { nas indústrias implantadas com benefícios fiscais e com base nas novas formas de organização do } \\
\text { trabalho. }\end{array}$} \\
\hline \multicolumn{3}{|l|}{ Divino Marcos de Sena } \\
\hline \multicolumn{3}{|c|}{ Camaradas: livres e pobres em Mato Grosso (1808-1850) } \\
\hline Dissertação de mestrado & UFGD & Ano de defesa: 2010 \\
\hline \multicolumn{3}{|c|}{$\begin{array}{l}\text { Abordagem: pesquisa aspectos do cotidiano de trabalho de uma parcela da população livre e pobre, } \\
\text { constituída pelos camaradas, no Mato Grosso, entre os anos de } 1808-1850 \text {, em especial aqueles } \\
\text { estabelecidos em ambientes rurais. }\end{array}$} \\
\hline \multicolumn{3}{|c|}{ Grazihely Berenice Fernandes dos Santos Paulon } \\
\hline \multicolumn{3}{|c|}{$\begin{array}{l}\text { Tecendo a igualdade: reflexões sobre gênero e trabalho na rede de economia solidária em Dourados- } \\
\text { MS (2000-2008) }\end{array}$} \\
\hline Dissertação de mestrado & UFGD & Ano de defesa: 2010 \\
\hline \multicolumn{3}{|c|}{$\begin{array}{l}\text { Abordagem: trata da participação das mulheres na Rede de Economia Solidária da cidade de } \\
\text { Dourados, a partir do ano } 2000 \text {, e compreende as relações de trabalho e gênero no contexto do } \\
\text { modelo econômico alternativo da Economia Solidária. }\end{array}$} \\
\hline \multicolumn{3}{|c|}{ Juliano Alves da Silva } \\
\hline \multicolumn{3}{|c|}{ Capital e trabalho na formação de Aparecida do Taboado e na industrialização recente } \\
\hline Dissertação de mestrado & UFGD & Ano de defesa: 2012 \\
\hline \multicolumn{3}{|c|}{$\begin{array}{l}\text { Abordagem: discute o processo recente de implementação de indústrias na cidade Aparecida } \\
\text { do Taboado e da reestruturação produtiva, partindo da análise da legislação de isenção fiscal da } \\
\text { atualidade e a construção discursiva do desenvolvimentismo e do progresso, desde as décadas de } \\
1930 \text { e } 1940 \text {. }\end{array}$} \\
\hline
\end{tabular}


Tabela 2 - Compilação de dissertações e teses (pós-2000) (cont.)

\begin{tabular}{|l|l|l|}
\hline \multicolumn{4}{|l|}{ Adilson Rodrigues Silva } \\
\hline Sertão de Coxim: apossamentos de terras, conquistas e relações de trabalho (1830-1898) \\
\hline Dissertação de mestrado & UFGD & Ano de defesa: 2013 \\
\hline
\end{tabular}

Abordagem: pesquisa o desenvolvimento da produção pastoril e as relações de trabalho na região de Coxim, no antigo Sul de Mato Grosso - 1830-1898.

Rodrigo Salvador de Araujo

Justiça a ferro e fogo: os trabalhadores da mineração e siderurgia em Corumbá e a busca por direitos na Justiça do Trabalho (1960-1970)

\begin{tabular}{|l|l|l}
\hline Dissertação de mestrado & UFGD & Ano de defesa: 2013
\end{tabular}

Abordagem: trata das reivindicações dos trabalhadores da mineração e siderurgia, por meio dos processos trabalhistas da Junta de Conciliação e Julgamento de Corumbá, tramitados e julgados no período de 1962 a 1975.

Silvana Aparecida da Silva Zanchett

Histórias, memórias, significações e apropriações: pescadores profissionais de Coxim-MS (1967 a 2012)

\begin{tabular}{|l|l|l}
\hline Dissertação de mestrado & UFGD & Ano de defesa: 2013
\end{tabular}

Abordagem: estuda a história do trabalho a partir das memórias dos pescadores e das pescadoras da cidade de Coxim, compreendendo a constituição da Colônia de Pesca Z-2 Rondon Pacheco e seu papel na organização da categoria.

Natalia Scarabeli Zancanari

Estrada Boiadeira, sua história, seus peões e comitivas: do sul de Mato Grosso ao noroeste paulista (1915 a 1940)

\begin{tabular}{|l|l|l}
\hline Dissertação de mestrado & UFGD & Ano de defesa: 2013
\end{tabular}

Abordagem: discute o modo de vida dos peões de boiadeiro na condução do gado durante sua passagem em comitivas pela Estrada Boiadeira, que fazia a ligação entre o sul de Mato Grosso e o noroeste do estado de São Paulo, especialmente entre os anos de 1915 e 1940.

Cássia Queiroz da Silva

Pobres livres em Sant'Anna do Paranahyba - século XIX

\begin{tabular}{|l|l|l}
\hline Dissertação de mestrado & UFGD & Ano de defesa: 2014
\end{tabular}

Abordagem: analisa a presença de homens e mulheres pobres livres que viveram em Sant'Anna do Paranahyba, no sul da província de Mato Grosso, no século XIX, sobretudo a partir de 1828 e ao longo do período imperial, construindo uma reflexão a respeito de seus modos de vida e de trabalho.

Elaine Aparecida Cancian de Almeida

Nos "confins do sertão" de Miranda: ocupação da terra, economia e trabalho (1830-1892)

\begin{tabular}{|l|l|l|}
\hline Tese de doutorado & UFGD & Ano de defesa: 2014
\end{tabular}

Abordagem: pesquisa a ocupação do território de Miranda, a formação das propriedades rurais e o processo de legalização das terras, nos anos de 1830 a 1892. Nesse ambiente, a autora estuda os trabalhadores escravizados e pobres livres, especialmente os camaradas, e demais indivíduos envolvidos no processo de ocupação, formação e exploração das terras.

Carlos Alexandre Herreira

Os trabalhadores da pecuária pantaneira em ação: a trajetória dos meninos-peões na Justiça do Trabalho (1978-1984)

\begin{tabular}{|l|l|l}
\hline Dissertação de mestrado & UFGD & Ano de defesa: 2015
\end{tabular}

Abordagem: discute os embates travados entre os meninos peões e os fazendeiros do Pantanal na Justiça do Trabalho de Corumbá, por meio das reclamações trabalhistas ajuizadas pelos menores, entre 1978 e 1984. 
Tabela 2 - Compilação de dissertações e teses (pós-2000) (cont.)

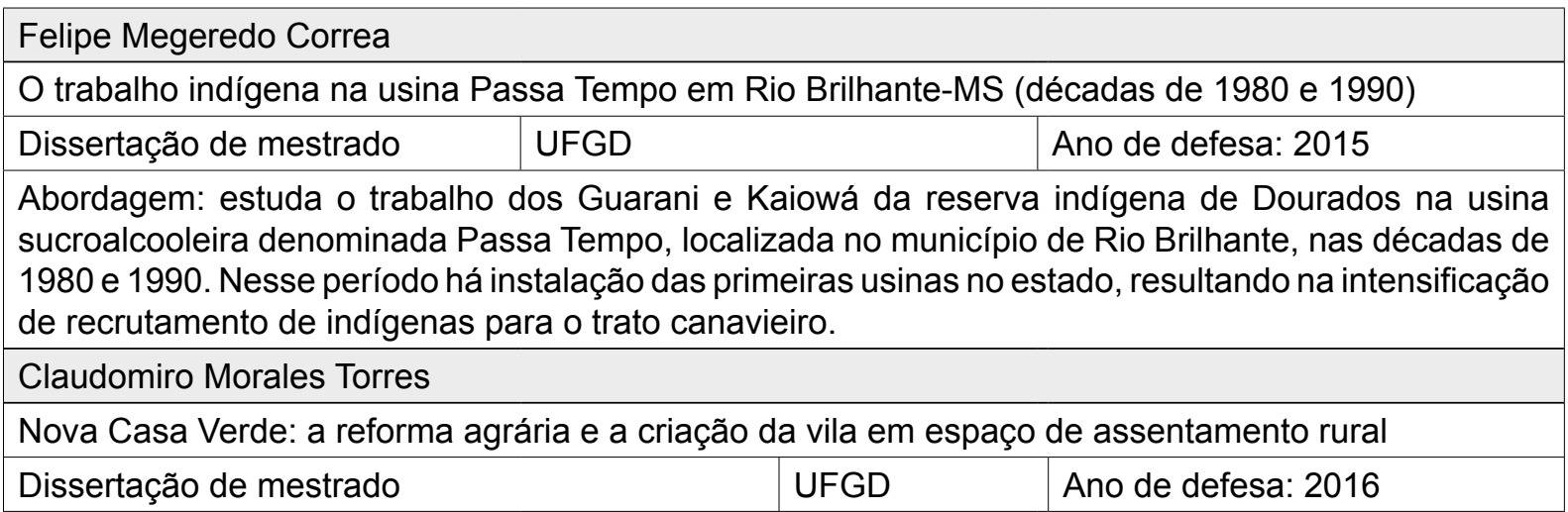

Abordagem: trata da luta pela terra na década de 1980 e a formação do núcleo urbano Nova Casa Verde pelos camponeses assentados em projeto de reforma agrária, destacando as histórias e memórias de "brasiguaios" e demais trabalhadores.

Ana Paula Dias Padilha

A Justiça do Trabalho em Mato Grosso do Sul: relações de trabalho no contexto das transformações políticas da década de 1990

\begin{tabular}{|l|l|l}
\hline Dissertação de mestrado & UFGD & Ano de defesa: 2016
\end{tabular}

Abordagem: discute as relações de trabalho no estado de Mato Grosso do Sul, no período marcado pela introdução da política neoliberal no Brasil, iniciada com o presidente Fernando Collor de Mello (1990-1992). As fontes privilegiadas dessa pesquisa foram os dissídios coletivos julgados pelo Tribunal Regional do Trabalho da $24^{a}$ Região, localizado em Campo Grande.

Beatriz dos Santos de Oliveira Feitosa

Entre os "imprescindíveis" e os "redundantes": olhares sobre constituição de espaços e mundo do trabalho rural na Região Norte de Mato Grosso do Sul contemporâneo

\begin{tabular}{|l|l|l|}
\hline Tese de doutorado & UFMT & Ano de defesa: 2016 \\
\hline
\end{tabular}

Abordagem: pesquisa a dinâmica de ocupação territorial no norte de Mato Grosso do Sul, concluindo que houve uma construção de territorialidades que determinou as relações de trabalho, a exclusão de trabalhadores e criou contingentes de humanos "redundantes".

Cláudia Delboni

Histórias de mulheres dos assentamentos Ernesto Che Guevara e João Batista na luta pela terra em Sidrolândia-MS: vivências, consentimentos, rupturas e continuidades

\begin{tabular}{|l|l|l}
\hline Tese de doutorado & UFGD & Ano de defesa: 2017
\end{tabular}

Abordagem: discute a trajetória de mulheres, do acampamento ao assentamento, no município de Sidrolândia.

Guilherme Luís General Miranda

A trajetória de mulheres migrantes do assentamento Itamarati I: relações de gênero e trabalho

\begin{tabular}{l|l|l}
\hline Dissertação de mestrado & UFGD & Ano de defesa: 2017
\end{tabular}

Abordagem: estuda as memórias e representações de mulheres migrantes camponesas, abordando as trajetórias, experiências e cotidiano, e problematizando as relações de gênero e trabalho ao longo das trajetórias de vida.

Rejane Trindade Rodrigues

Escravidão e liberdade em Sant'Anna do Paranahyba, Sul de Mato Grosso (1828-1888)

\begin{tabular}{l|l|l}
\hline Dissertação de mestrado & UFGD & Ano de defesa: 2017
\end{tabular}

Abordagem: analisa a história da liberdade e da escravidão no contexto do Império (1828-1888), na Província de Mato Grosso, especialmente em Sant'Anna do Paranahyba, com foco nos povos originários Cayapó, os negros e negras escravizados e os pobres livres. 
Tabela 2 - Compilação de dissertações e teses (pós-2000) (fim)

\begin{tabular}{|c|c|c|c|}
\hline \multicolumn{4}{|l|}{ Elisandra Tomascheski } \\
\hline \multicolumn{4}{|c|}{$\begin{array}{l}\text { "Dos lugares deixados, aos lugares chegados": história de mulheres brasiguaias do Assentamento } \\
\text { Itamarati-MS }\end{array}$} \\
\hline Dissertação de mestrado & & UFGD & Ano de defesa: 2018 \\
\hline \multicolumn{4}{|c|}{$\begin{array}{l}\text { Abordagem: pesquisa a migração de retorno de brasileiras do Paraguai, a luta pela terra e a conquista } \\
\text { do assentamento, a partir de trajetórias de mulheres camponesas. }\end{array}$} \\
\hline \multicolumn{4}{|c|}{ Juliano Alves da Silva } \\
\hline \multicolumn{4}{|c|}{$\begin{array}{l}\text { Cultura, trabalho e memória: a trajetória de trabalhadores e trabalhadoras nas cidades de Três } \\
\text { Lagoas-MS e Aparecida do Taboado-MS }(1980-2015)\end{array}$} \\
\hline Tese de doutorado & UFGD & & Ano de defesa: 2020 \\
\hline
\end{tabular}

O levantamento aqui apresentado considerou as informações fornecidas pelos bancos de teses e dissertações dos programas de pós-graduação em História da Universidade Federal de Mato Grosso (UFMT) e UFMS/UFGD, ambos criados em 1999. Outra fonte de informação foram as referências bibliográficas arroladas nas obras historiográficas de diversos temas regionais (publicações ou mimeografadas). Com isso, podemos não ter alcançado trabalhos realizados em programas de pós-graduação em outros estados da federação: encontramos apenas 12 trabalhos realizados fora da UFMS/UFGD e UFMT, e ainda algo dessas instituições pode ter escapado ao levantamento. ${ }^{24}$

Em uma avaliação quantitativa, em quatro décadas (1980-2020), encontramos 39 trabalhos, grande parte ao nível de mestrado, o que dá uma média de pouco menos de um trabalho por ano $(0,97)$. A maioria absoluta está concentrada nas duas décadas do século $X X I$, o que coincide com a efetivação dos mestrados e doutorados nos dois estados.

Quanto aos assuntos abordados dentro da grande temática mundos do trabalho, é recorrente o estudo das relações de trabalho no mundo rural. Compreensível esse enfoque por se tratar de Mato Grosso e Mato Grosso do Sul, estados nos quais a sociedade, até muito dentro do século XX, foi predominantemente rural e a economia continua sendo especialmente rural, em que pese o avanço do capitalismo no campo ter modificado profundamente a empresa agrícola, hoje bastante diferente do que eram as fazendas. Mesmo os centros urbanos, diminutos, tiveram sempre relação de dependência com o mundo rural, o que não elimina a importância da vila e da cidade na determinação da política formal, por exemplo, que se manifesta nas tribunas, câmaras, assembleias, "palácios" e tribunais urbanos.

24 Não consideramos aqui a diversidade de artigos científicos em revistas especializadas e anais de eventos, resultados de pesquisas de mestrado e doutorado ou não originadas nestes âmbitos. A estruturação de grupos de pesquisa, de laboratórios e centros de documentação e de pesquisa nas universidades de Mato Grosso e Mato Grosso do Sul levou à diversificação da pesquisa na área de História e muito tem se produzido sobre a temática aqui analisada. 
Nesse mundo rural, a relação com a terra determinou a formação dessa sociedade. Para muitos, não ter terra e, para alguns, deter o domínio de muita terra é o que determina o lugar que esses sujeitos ocupam nas relações de produção e de classe. Daí a preocupação recorrente dos pesquisadores em compreender esse mundo do trabalhador rural.

Desde as primeiras pesquisas, os homens, as mulheres e as crianças desse mundo rural são estudados na produção e reprodução da vida, em sua relação com a natureza e na imposição do capital na exploração da natureza e das pessoas. Emblemáticos dessa relação são os trabalhadores do mundo ervateiro, no extremo sul do Mato Grosso. Os primeiros trabalhos das décadas de 1980 e 1990 iniciaram essa tradição historiográfica de buscar compreender esses sujeitos na relação com a natureza e o capital. O trabalho nos ervais e, especialmente o domínio econômico, territorial e da força de trabalho construído pela empresa Matte Larangeira, do final do século XIX até a década de 1940, vem sendo abordado por diversos pesquisadores desde o início das pesquisas no e sobre o Sul de Mato Grosso. Em muito contribuíram essas pesquisas para a historiografia nacional, ao enunciar outros sujeitos do trabalho e outras estruturas do capital em regiões até então compreendidas como "vazios" humanos. Os indígenas, habitantes pretéritos dessa região, desapossados de suas terras tradicionais, foram parte substancial dos trabalhadores da erva-mate, como também continuam sendo força de trabalho de outros ciclos produtivos até o tempo presente.

A característica fronteiriça da região também impõe ao historiador romper com as fronteiras nacionais que muitas vezes determinam a historiografia. Se os trabalhadores e o capital não respeitavam as fronteiras, não poderia o historiador querer cercar seu tema na fronteira nacional. Ao evidenciar a presença do trabalhador paraguaio na Cia. Matte Larangeira, as pesquisas sobre o mundo ervateiro contribuíram ainda para uma história transnacional por estudar formas de organização da produção e do trabalhador na região fronteiriça entre Brasil, Argentina e Paraguai, espaço de circulação constante de pessoas e de mercadorias. Com essas pesquisas abrem-se também novas perspectivas de se compreender a configuração da classe trabalhadora.

A fronteira, como categoria analítica, mas também como fenômeno político-social, é algo recorrente nos trabalhos acadêmicos levantados, e isso se explica pela característica da região. A fronteira marca a história da região desde o período inicial da colonização, no século XVI, quando era disputada por portugueses e espanhóis. Com a formação dos estados nacionais no Cone Sul americano, a fronteira será uma determinação para se compreender o avanço do movimento do capital e do trabalho. Essa preocupação estará presente nas interpretações dos pesquisadores que estudam o trabalhador relacionado ao território, como também nas pesquisas que buscam compreender os projetos de construção da nacionalidade, como foi o caso da implementação da estrada de ferro Noroeste do Brasil, objeto de pesquisas desde a década de 1990. Os estudos realizados sobre a implementação dessa ferrovia como projeto 
político-estratégico de avanço do Estado brasileiro para a fronteira oeste (entre 1904-1915), desvelaram categorias de trabalhadores e formas de organização do trabalho que permitem vislumbrar um sertão carregado de violências, mas também de resistência, de convergência de nacionalidades e de culturas.

Os projetos nacionais para a região, por sinal, são algo que está entre as preocupações dos pesquisadores e das pesquisadoras também desde o início, sob forte influência da abordagem do historiador Alcir Lenharo, ao estudar e orientar pesquisas sobre os projetos varguistas para o Mato Grosso. ${ }^{25}$ Por se tratar de uma região distante do centro do poder político e econômico, por muito tempo Mato Grosso apareceu para os governos centrais mais como uma perspectiva, algo a ser edificado, do que propriamente constituído. Daí inclusive vem a ideia de "vazio" demográfico e o projeto ideológico do Estado Novo da "Marcha para o Oeste" que previa a ocupação do sertão. Para além dos discursos, essas ideias se materializaram em políticas e projetos de colonização que tiveram continuidade no período da ditadura civil-militar (1964-1985), os quais redesenharam a propriedade da terra, mantendo, contudo, a alta concentração fundiária, a expulsão de povos originários ou o "confinamento" desses grupos em pequenas áreas, e a obstaculização do acesso à propriedade aos pobres da terra.

Essa conformação marcará, portanto, a historiografia do mundo do trabalho na região e delineará as pesquisas recentes que buscam compreender o campesinato contemporâneo, com leituras de gênero e classe, emergindo novos sujeitos, novos temas e objetos, na historiografia do trabalho, como a mulher camponesa e os "brasiguaios" (migrantes brasileiros de retorno do Paraguai nas décadas de 1980 e 1990). Esses novos sujeitos em atuação no Mato Grosso do Sul construíram também novas organizações da classe trabalhadora, como o Movimento dos Trabalhadores Rurais Sem Terra (MST), que desde o seu nascedouro plantou raízes no estado pela atuação dos pobres da terra, e influenciou na definição de temas de pesquisas nas décadas posteriores, as quais construíram interpretações inovadoras sobre a questão agrária e camponesa, a partir da disjuntiva terra de trabalho $X$ terra de negócio, acompanhando os debates historiográficos nacionais.

Os indígenas "entram para a história" do Brasil como selvagens, mas também como trabalhadores para outrem e estranhos em sua própria terra. Nos sertões são presença constante no mundo do trabalho e por muito tempo continuaram estranhos à historiografia. Com o avanço do capitalismo nessas fronteiras, os aldeamentos e cercamentos das terras contribuíram para que os indígenas compusessem parte significativa da reserva de força de trabalho. Presentes na história, aparecem na historiografia do trabalho e dos trabalhadores, em que pese de início ainda como parte igual ao trabalhador não indígena. Aos poucos, a historiografia tem inovado na interpretação dessas histórias, atenta à complexidade

25 LENHARO, Alcir. Colonização e trabalho no Brasil: Amazônia, Nordeste e Centro-Oeste. Campinas: Editora da Unicamp, 1986. 
da disjuntiva terra e trabalho para os povos originários: a terra "como mercadoria para os capitalistas e a relação dos indígenas distinta da propriedade capitalista e coletivista, terra como lugar de produção da vida biológica e cultural" e o trabalho como valor de troca, "o indígena como mão de obra para as empresas agrícolas" e como valor de uso "como atividade de produção da vida". ${ }^{26}$

Essas temáticas dos mundos do trabalho do tempo recuado ou de um tempo presente contribuíram, ainda, para a discussão metodológica na produção historiográfica local, com a utilização da história oral, por exemplo, e do diálogo com outras ciências, como a Antropologia, e dentro da História com áreas como a história econômica, política, cultural e com perspectivas teórico-metodológicas predominantemente da história social, com viés teórico dos marxismos de tradição inglesa e francesa, bem como da nova história.

A inovação historiográfica da década de 1980, no Brasil, ampliou as possibilidades de abordagem da história social do trabalho em relação aos sujeitos, objetos e vestígios históricos. As pesquisas aqui levantadas, em algum sentido, dialogam com essa tradição e demonstram a seriedade do trabalho de arquivo, do escarafunchar acervos, da releitura de fontes oficiais como relatórios de província, processos crimes e da Justiça do Trabalho, bem como o uso da imprensa e de arquivos de organizações dos trabalhadores, acervos privados, obras literárias e memorialistas.

Desse esforço surgem, no século $\mathrm{XXI}$, pesquisas instigantes sobre trabalhadores escravizados, pobres livres e indígenas no século XIX, especialmente no trabalho da terra. Revelam, ainda, histórias de peões adultos e crianças nas fazendas e comitivas de gado, no trabalho tradicional dos pescadores e pescadoras, e no trabalho escravo contemporâneo que marca as contradições do desenvolvimento desigual e combinado na periferia, em que se têm lado a lado modernas técnicas de produção de mercadorias e formas arcaicas de relações de trabalho e de exploração/sangria da terra e de sua gente.

Essa historiografia nos ensina, ainda, que nesse mundo dos sertões o historiador deve estar atento às determinações geográfico-naturais, como a diversidade da flora, o ciclo das águas no Pantanal e os cursos dos rios, pois esses influenciam na ocupação e construções humanas, como as cidades, enfim determinam a história. Essas paisagens não se cercam nas fronteiras nacionais, especialmente até a primeira metade do século $X X$, quando ainda a natureza parecia levar vantagem em relação à técnica que se impunha pelo avanço do capitalismo no oeste. Pessoas e mercadorias seguiam o curso de veios naturais, como os grandes rios Paraná e Paraguai, e esses veios desconhecem fronteiras. Daí a importância da perspectiva de uma história comparada ou transnacional do mundo do trabalho que desvele as proximidades e distanciamentos das histórias nacionais na Bacia Platina.

26 OLIVEIRA, Vitor Wagner Neto de. Etnocídio e resistência indígena na história do Brasil: contribuições da tradição marxista para uma análise militante. In: MENEZES, Jean Paulo Pereira de; JESUS, Nataly Batista de (org.). Estudo e militância na sociedade de classes. Goiânia: Editora Philos, 2019. p. 85-111, p. 106. 
As determinações não são, contudo, somente geográfico-naturais. Diríamos mesmo que não há determinações apenas naturais (da natureza), porque determinante na história são as relações do homem com a natureza. Uma paisagem sem gente (nela ou em relação a ela) não existe, pois é o atuar na paisagem, o ver e retratar a paisagem é que dá historicidade a essa natureza. Portanto, essas determinações são também política, econômica e social. Nesse sentido, a guerra da Tríplice Aliança com o Paraguai foi um divisor de águas para a história do Sul de Mato Grosso e marcou a historiografia regional; e também as análises mais recuadas sobre a história dos trabalhadores escravizados, livres e indígenas, e mesmo a história contemporânea, dada as marcas na memória coletiva das populações nos dois lados da fronteira Brasil/Paraguai. Também marcou a ocupação urbana do oeste, com a edificação de instituições militares que contribuíram para a disciplinarização da população local para o trabalho (negros, indígenas e pobres, na condição de escravos ou livres).

O sertão não é um local isolado, ele é parte constituída e constituinte do todo nacional e, neste caso, regional platino. Os núcleos urbanos, especialmente aqueles fundados em entroncamentos de vias ou como portos, são cosmopolitas porque se configuram em lugares de passagem, de trânsito, mobilidade característica de regiões em transição, de fronteira móvel. Aí a classe operária se faz distinta, mas desde o século XIX esteve conectada com o movimento operário nacional, regional platino e internacional.

As pesquisas têm trazido à luz sujeitos urbanos em luta e resistência, homens e mulheres do século XIX ao XXI, como marítimos, portuários, operários da construção civil, pescadores, operários da siderurgia, bancários, professores, ferroviários e operários da indústria. Essas histórias evidenciam a constituição pelos operários de espaços de culturas políticas, como sindicatos e associações, e na interação com a política de Estado em partidos e movimentos. Desvela ainda, a constituição de lugares de culturas operárias, associações culturais e clubes esportivos.

Pesquisas no campo da história do tempo presente apontam para continuidades e rupturas da história da classe trabalhadora em Mato Grosso do Sul, quando consideradas as metamorfoses no mundo do trabalho com o advento do neoliberalismo no Brasil na década de 1990. A imposição de outras nuances de disciplina do trabalho, permitidas pela inovação tecnológica introduzida na linha de produção, levou à reconfiguração da classe trabalhadora e tem impactado nas organizações de representação da classe. Essas transformações na periferia da periferia (porque periferia de um centro à margem do capitalismo) se apresentam de outra monta e chegam pelos serviços de empresas estatais privatizadas na década de 1990 (como a de telefonia) e de instituições financeiras. Chegam, também, pela implementação de projetos de desenvolvimento industrial com base em isenção de impostos e mão de obra barata, que atrai para a região indústrias, na maioria dos casos de baixa complexidade tecnológica, mas que adotam as novas formas de organização do trabalho flexível, desenhando um hibridismo de fordismo e toyotismo. 
A apresentação integrada entre as pesquisas que construímos aqui permite uma visão geral, mas não quer forjar uma unidade onde não existe. O diálogo entre os diversos temas e as diversas pesquisas foi construído na análise e não estava, a priori, concebido pelos pesquisadores. Em todo caso, ele permitiu perceber que há continuidades e descontinuidades nos objetos e formas de abordagem.

A diversidade de temas, abordagens, sujeitos e fontes descritas neste tópico não quer, contudo, esconder ausências, especialmente de outros sujeitos, e mesmo o quão embrionária é essa historiografia. Quantitativamente e, em alguns casos, qualitativamente estamos distantes de abarcar a diversidade de problemáticas da complexa história do trabalho e dos trabalhadores e trabalhadoras nesses sertões: para efeito de exemplo, é notória a ausência de pesquisas sobre as organizações políticas dos trabalhadores, a relação desses com a política formal e a classe trabalhadora no período da ditadura civil-militar.

\section{Considerações finais}

As AUSÊNCIAS OU FRAGILIDADES das pesquisas na área da história do trabalho e dos trabalhadores no Mato Grosso do Sul (e que, com certeza, não se restringe a esta área da História) tem a ver com a compreensão tradicional da ausência de classes e de luta de classes no oeste, mas também com um movimento que é nacional (dinamização da pesquisa por meio da disseminação dos programas de pós-graduação, que, como vimos, chega à região no último ano do século XX e não se amplia muito a partir de então), de transformações historiográficas nacional e internacional (como a ampliação e fragmentação da historiografia) ${ }^{27}$ e conjuntural (das transformações políticas e econômicas iniciadas com a queda dos estados operários burocratizados que tem o marco em 1989).

O "fim do trabalho" e da classe operária, aventados por teorias pós-estruturalistas a partir do final da década de 1990 - e que de certa forma impactaram na produção de pesquisas (ou falta de produção) sobre o tema - parece estar sendo superado pela história vivida nesse século XXI em que, de crise em crise, a economia neoliberal e o projeto de globalização têm sido questionados e enfrentados com antigos e novos métodos de lutas da "classe que vive do trabalho". ${ }^{28}$

A persistência da produção de pesquisas sobre os mundos do trabalho, no decorrer das quatro décadas analisadas, demonstra, por outro lado, que há uma consistência que não se interrompe pelos abalos advindos da história e da ciência história.

As perspectivas abertas por essas pesquisas são imensas. Alguns objetos foram inaugurados, mas merecem ser revisitados; problemas foram levantados e podem ser

27 BATALHA, Claudio Henrique de Moraes. A historiografia da classe operária no Brasil: trajetória e tendências. In: FREITAS, Marcos Cezar (org.). Historiografia brasileira em perspectiva. São Paulo: Contexto, 1998. p. 145-158, p.154.

28 ANTUNES, Ricardo. Os sentidos do trabalho: ensaio sobre a afirmação e a negação do trabalho. São Paulo: Cortez, 2000. 
desenvolvidos sob a luz de novas fontes e outras teorias. A história dos trabalhadores e das trabalhadoras do oeste não é uma versão interiorana de uma história do operariado mundial ou nacional. O que não impede de vermos relações, proximidades e interações, pois trata-se de sujeitos que fazem história sem considerar as linhas fronteiriças, são, nesse sentido, internacionais.

Por fim, se a classe trabalhadora no Brasil é eminentemente negra, no oeste é também indígena, feminina, transnacional e rururbana. Compreender esses sujeitos, suas organizações e a interação com esferas da política, da economia e da cultura deve ser tarefa da História. Mãos à obra!

Recebido em: 03/06/2020

Aprovado em: 25/07/2020 